\title{
Viral Metagenomics on Blood-Feeding Arthropods as a Tool for Human Disease Surveillance
}

\author{
Annika Brinkmann *, Andreas Nitsche and Claudia Kohl \\ Robert Koch Institute, Centre for Biological Threats and Special Pathogens, Seestrasse 10, Berlin 13353, Germany; \\ NitscheA@rki.de (A.N.); KohlC@rki.de (C.K.) \\ * Correspondence: BrinkmannA@rki.de; Tel.: +49-30-18754-2591
}

Academic Editor: Patrick C. Y. Woo

Received: 6 July 2016; Accepted: 11 October 2016; Published: 19 October 2016

\begin{abstract}
Surveillance and monitoring of viral pathogens circulating in humans and wildlife, together with the identification of emerging infectious diseases (EIDs), are critical for the prediction of future disease outbreaks and epidemics at an early stage. It is advisable to sample a broad range of vertebrates and invertebrates at different temporospatial levels on a regular basis to detect possible candidate viruses at their natural source. However, virus surveillance systems can be expensive, costly in terms of finances and resources and inadequate for sampling sufficient numbers of different host species over space and time. Recent publications have presented the concept of a new virus surveillance system, coining the terms "flying biological syringes", "xenosurveillance" and "vector-enabled metagenomics". According to these novel and promising surveillance approaches, viral metagenomics on engorged mosquitoes might reflect the viral diversity of numerous mammals, birds and humans, combined in the mosquitoes' blood meal during feeding on the host. In this review article, we summarize the literature on vector-enabled metagenomics (VEM) techniques and its application in disease surveillance in humans. Furthermore, we highlight the combination of VEM and "invertebrate-derived DNA" (iDNA) analysis to identify the host DNA within the mosquito midgut.
\end{abstract}

Keywords: viral metagenomics; hematophagous arthropods; blood-feeding arthropods; vector-enabled metagenomics; xenosurveillance; emerging infectious diseases; virus surveillance; mosquitoes

\section{Surveillance of Emerging Viruses}

The recent epidemic of Ebola virus in Africa as well as the emergence of a hitherto unknown virus known as Middle East respiratory syndrome coronavirus (MERS-CoV), Bas-Congo virus in central Africa or of severe fever with thrombocytopenia syndrome virus (SFTSV) in China have repeatedly shown the global impact of emerging infectious diseases (EIDs) on economics and public health [1-4]. These EIDs, more than $60 \%$ of which are of zoonotic origin, are globally emerging and re-emerging with increased frequency [5]. Surveillance and monitoring of viral pathogens circulating in humans and wildlife and the identification of EIDs at an early stage is challenging. Many potential emerging viruses of concern might already be infecting humans or wildlife but await their detection by disease surveillance. In remote and underdeveloped regions of the world, often no attention is paid towards possible infectious disease cases until a threshold of serious cases and deaths appears in a cluster and certain epidemic properties are reached [3]. Some viruses might just be overlooked at population levels until they spread or re-emerge and become epidemic in another region or time. An effective strategy in virus surveillance would need to survey simultaneously a wide range of viral types in a large number of human and wildlife individuals in order to detect viruses before spreading. For example, the EcoHealth Alliance within the surveillance program PREDICT seeks to identify new EIDs before they emerge or re-emerge. Therefore, wildlife animals that are likely to carry 
viruses with zoonotic potential, e.g., bats, rodents, birds and primates, are sampled frequently [6,7]. However, collecting swabs or blood from sufficient numbers of wildlife individuals and the subsequent identification of viruses is challenging. The solution for overcoming this challenge might be presented by the disease vector itself. Blood feeding arthropods feed on blood from a wide range of hosts including humans, mammals and birds [8]. Therefore, they act as "syringes", sampling numerous vertebrates and collecting the viral diversity over space, time and species. Xenosurveillance and vector-enabled metagenomics (VEM) are surveillance approaches that can exploit mosquitoes to capture the viral diversity of the animal, human or plant host the mosquito has fed on (Figure 1). Xenosurveillance, a term introduced by Brackney et al., refers to the identification of viral pathogens from total nucleic acids extracted from mosquito blood meals, either by next-generation sequencing (NGS) or conventional PCR assays [9]. Recent developments in NGS and viral metagenomics, which is the shotgun sequencing of viral nucleic acids extracted from purified virus particles, offer great opportunities for the characterization of the complete viral diversity in an organism or a population [10]. VEM, a technique used to sequence purified viral nucleic acids directly from insect vectors, has already been used to detect both animal and plant viruses circulating in vectors $[11,12]$. This review summarizes findings from xenosurveillance efforts as well as VEM studies using mosquitoes, since both approaches combine sampling of multiple individuals of blood-feeding arthropods with the high-throughput properties of NGS.

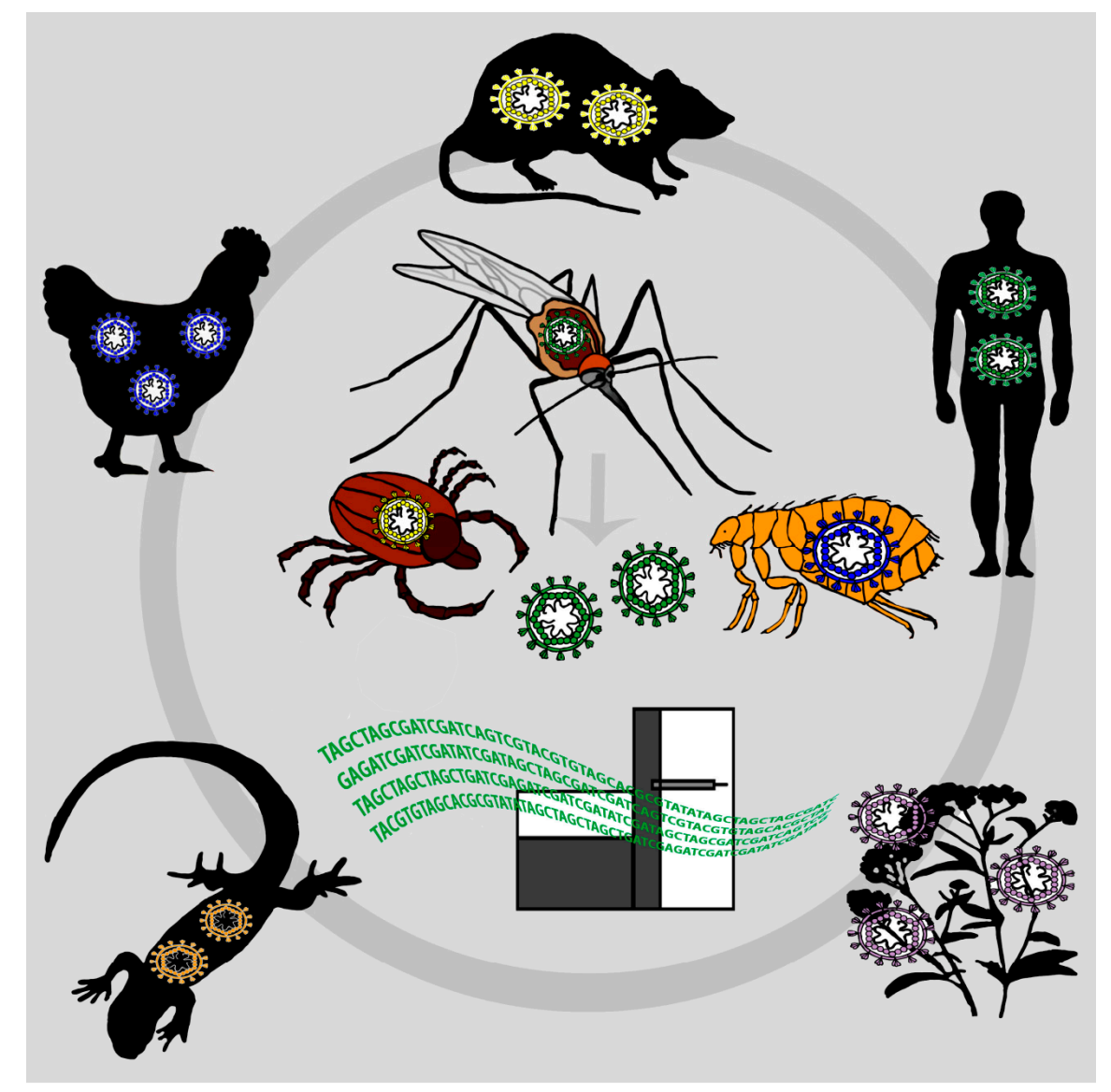

Figure 1. Vector-enabled metagenomics (VEM) as a tool for virus surveillance: Hematophagous arthropods feed on a wide range of hosts. The blood meals of mosquitoes, ticks, fleas, flies and midges therefore reflect the viral diversity of the host on which the arthropod has fed on, including mammals, birds, reptiles, humans and plants. Sequencing of such arthropods' blood meals with next-generation sequencing technologies can shed light on the viral diversity of several host species within a distinct region and can be used as a tool for viral disease surveillance. 


\section{Mosquitoes as "Flying Syringes" for Virus Surveillance}

To our knowledge, there are only few mosquito virome studies in the database as yet [11,13-19]. In this review, mosquito viruses are defined as follows: mosquito-infecting viruses and mosquito-borne viruses. Mosquito-infecting viruses infect mosquitoes naturally and replicate in mosquito cells in vitro, but do not replicate in vertebrate cells or infect humans or other vertebrates [20]. Novel NGS technologies have led to the discovery of numerous mosquito-infecting viruses, most of them within the families Parvoviridae, Flaviviridae, Togaviridae, Rhabdoviridae, Bunyaviridae, Reoviridae, Mesoniviridae, Tymoviridae and Birnaviridae [11,17]. In contrast, mosquito-borne viruses replicate within the mosquito, but can also be transmitted biologically to vertebrates and infect vertebrate cells [21]. The majority of mosquito-borne viruses belong to the families Togaviridae, Flaviviridae and Bunyaviridae, comprising highly pathogenic viruses such as Dengue virus, Chikungunya virus, Yellow fever virus, Japanese encephalitis virus, West Nile virus and Rift Valley fever virus [22,23].

Most studies on mosquito viruses focus on mosquito-infecting viruses or mosquito-borne viruses, neglecting the presence of vertebrate viruses originating from the blood of the mosquitoes' host that have accumulated in the mosquitoes' intestine during blood feeding. Shi et al. give an example of such viruses in the metagenomic survey on viral abundance in mosquitoes (Culex tritaeniorhynchus, Anopheles sinensis, Armigeres subalbatus and Culex fatigans) from Hubei province in China [13]. 3.6\% of all viruses found in the metagenomics survey were neither mosquito-infecting nor mosquito-borne, but assumed to be of vertebrate origin. These viruses were closely related to torque teno sus virus 1 (family Anelloviridae, genus Iotatorquevirus) which is widely distributed in pigs [24]. In addition, sequences belonging to the genus Parvovirus were identified that were closely related to porcine parvovirus. Mosquitoes were collected from cowsheds and pigpens located in different areas of Hubei province. Since mosquitoes are not known to be vectors of torque teno sus virus 1 and porcine parvovirus, it is likely that the mosquito had ingested viremic blood during blood feeding on diseased pigs.

Barbazan et al. reported a first targeted approach for vectored vertebrate virus detection using mosquito blood meals. They collected blood-engorged mosquitoes near a poultry farm during an outbreak of avian influenza in Thailand and found H5N1 virus sequences in the mosquito pools tested by using RT-PCR [25].

The combination of using mosquitoes as "flying syringes" and NGS for virus surveillance was introduced by $\mathrm{Ng}$ and others using the term vector-enabled metagenomics (VEM) [11]. The group sequenced mosquito samples from different sites in California and found a broad range of already known and highly diverse DNA viruses, including anelloviruses, herpesviruses, poxviruses and papillomaviruses. These viruses infect a wide range of hosts including humans, mammals and birds and are not assumed to be transmissible by mosquitoes. Viruses of possible human origin were human papillomavirus 23 (HPV23), human herpesvirus 1 and human papillomavirus type 112 (HPV112). Human herpesvirus 1 is a neurotropic $\alpha$-herpesvirus that causes infections of epithelia lining oral mucosa, conjunctiva, cornea and skin [26]. Papillomaviruses can infect epithelial cells of the skin or inner lining of tissues $[27,28]$. More than $80 \%$ of healthy human skin is asymptomatically infected with different papillomaviruses [29]. It is possible that both papillomaviruses and herpesvirus have been transferred from the human skin to the mosquito during feeding. Viruses belonging to the Anelloviridae can be identified in blood [30]. Anelloviruses infect humans, vertebrates and marine mammals [31,32]. It is possible that anelloviruses in the mosquito virome were ingested from the viremic hosts during blood feeding.

\subsection{Feasibility Studies}

If VEM and such approaches will be used to survey human and animal viruses circulating in a given area, it is of importance to understand how long viruses last in the mosquito's blood meal. Following the introduction of VEM by $\mathrm{Ng}$ and others, several studies have shown that both DNA and RNA viruses are still detectable in the mosquito blood meal at least $24 \mathrm{~h}$ after ingestion. 
Kading et al. used Aedes albopictus mosquitoes as flying "biological syringes" to draw blood for virus titer determinations in small lab-housed vertebrates [33]. The lab animals (avian: chicks Gallus gallus, house sparrows Passer domesticus; mammals: hamsters Mesocricetus auratus) were experimentally infected with West Nile virus (Flaviviridae) and Highlands J virus (Togaviridae). Blood samples were recovered from the mosquitoes' blood meals after feeding on the mentioned lab animals and compared to blood drawn by syringe. Virus titers derived from these two methods were not significantly different. The technique has also been successfully used on small reptiles before, but was not compared to standard methods and viremia titers were not measured [34].

In a second feasibility study to use mosquito blood meals for virus detection with a novel approach called xenosurveillance, Grubaugh and others developed a laboratory model to explore variables influencing detection of human immunodeficiency virus 1, West Nile virus, Pirital virus, Lassa virus and Chikungunya virus in blood-fed Anopheles gambiae mosquitoes [9]. The pathogen load and the stability of viral nucleic acids present in the mosquitoes' blood meals were determined at different time points after blood feeding by qRT-PCR and NGS. They showed that viral nucleic acids could be detected from blood-fed Anopheles gambiae mosquitoes for up to $24 \mathrm{~h}$ post feeding. Furthermore, RNA virus recovery from mosquitoes that were allowed to feed artificially on a membrane feeding apparatus and from mosquitoes fed on hamsters with active replicating infections did not differ significantly.

To assess the feasibility of xenosurveillance for the detection of human pathogens in real settings, indoor resting, blood-fed Anopheles gambiae mosquitoes were collected in villages in northern Liberia. Using NGS, the research group found human Epstein-Barr virus (EBV), a highly prevalent gamma-herpesvirus that infects B-lymphocytes [35,36]. It is therefore likely that EBV was ingested from the human white blood cells in blood the mosquito fed on. In one pooled mosquito blood sample, canine distemper virus (CDV) was found, and, even more interestingly, genetic material of canine origin in the same pool.

A third feasibility study for using mosquito blood meals as a tool for human and animal virus surveillance was conducted by Yang and others [37]. The study explored the viral nucleic acid stability at different time points after mosquito ingestion. Anopheles stephensi mosquitoes were fed with Dengue virus-infected blood, and the efficiency of recovering viral RNA was analyzed after serial time points by qRT-PCR and NGS. Results showed that viral Dengue RNA in the blood meal is gradually degraded but still detectable $24 \mathrm{~h}$ after blood feeding.

\subsection{Other Hematophagous Animals for VEM}

Since various blood-feeding animals may accumulate viruses of interest, VEM surveillance efforts should not be limited to mosquitoes exclusively. Here we summarize several groups of hematophagous arthropods and leeches that might be useful for surveillance purposes.

\subsubsection{Ticks}

Ticks (class Arachnida, subclass Acari) are a source of many highly pathogenic vector-borne diseases such as Crimean-Congo hemorrhagic fever virus (CCHFV) and tick-borne encephalitis virus (TBEV) [38-40]. To our knowledge, only a few studies have been published on tick metagenomes [41-44]. Blood digestion in ticks is a slow, intracellular process. Unlike mosquitoes, some tick species feed slowly for days on their host and concentrate their blood meals by excreting water and sodium ions [45]. It has been shown that host DNA is protected from degradation and can be recovered from the tick after feeding [46,47]. The metagenomic analysis of Rhipicephalus spp. ticks from Yunnan, China, revealed the presence of a virus belonging to the Anelloviridae that was closely related to torque teno canis virus, suggesting a vertebrate origin of the virus [42]. Anelloviruses, which are usually found in the blood of vertebrates, were also found in mosquito viromes $[11,13,30]$. For VEM, blood-engorged ticks could be sampled directly from the host body or be collected with flagging techniques [48]. However, success of VEM depends on the tick species and stage of life as 
some tick species feed on a single host during their whole life cycle and do not seek a new host after detachment [45].

\subsubsection{Midges}

Biting midges (Diptera, Ceratopogonidae, Culicoides Latreille), small blood-sucking flies, have been found in almost all parts of the world in all environments [49]. Female midges feed on a variety of hosts, and therefore a diversity of plant, animal and human viruses can be identified in the virome [50]. They transmit various culicoides-borne arboviruses, e.g., Schmallenberg virus in European ruminants, Bluetongue virus, Oropouche virus and African horse sickness virus [51-53]. Non-vertebrate viruses, such as faustovirus-like asfarviruses, have also been found by metagenomic analyses in hematophagous biting midges and their vertebrate hosts [54].

\subsubsection{Carrion Flies}

Wild-caught carrion flies (Calliphora nigribarbis and Aldrichina grahami) sampled near poultry farms have been used for the detection of H5N1 virus [55]. Also, Newcastle disease virus has been detected in carrion flies and correlated to a virus outbreak in a poultry farm nearby [56]. It is suspected that the viruses have been transported mechanically by the flies from chicken droppings and secretions or contaminated surfaces or have been actively ingested by the flies. Other examples of mechanically transmitted viruses by flies are the transmission of turkey coronavirus and rotavirus by domestic houseflies (Musca domestica) [57,58]. Furthermore, carrion flies have been used for the targeted detection of mammalian species DNA and biodiversity [59,60]. Since carrion flies feed on many vertebrate carcasses, it is feasible to use them for the detection of viruses from deceased animals.

\subsubsection{Bed Bugs}

Common bed bug (Cimex lectularius and Cimex hemipterus, family Cimicidae) infestations are increasing worldwide also in industrialized countries [61]. To our knowledge, there are no virome analyses of bed bugs. Since they live in close proximity to humans and are nocturnal blood feeders, bed bugs might be easily sampled and used for VEM. Bed bugs are wingless, obligate hematophagous ectoparasites and feed on bats, birds and mammals. Bed bugs are suspected of transmitting infectious agents [62]. Hepatitis B virus (HBV) has been detected in bed bugs but no biologic replication could be observed [61,63]. Furthermore, it has been demonstrated that human immunodeficiency virus (HIV) can be detected for eight days after ingestion of concentrated virus in experimental blood meals, with no active replication in bed bugs [64].

\subsubsection{Fleas}

Fleas (order Siphonaptera) are hematophagous insects which feed on mammals, including humans, and birds. They are known to transmit feline leukemia virus and myxoma virus $[65,66]$. To our knowledge, there are no virome or metagenomic analyses on fleas, and further studies are necessary to prove the concept of VEM on fleas.

\subsubsection{Bat Flies}

Bat flies (superfamily Hippoboscoidea, families Streblidae and Nycteribiidae) are specialized ectoparasititic insects only associated with bats [67]. They permanently live on the bat fur and wing membranes where they feed on the bat's blood. Bats are reservoir hosts for several emerging and re-emerging viral pathogens [68]. It is possible that also bat flies transfer such viruses among bats or bat workers, a fact that would make them excellent targets for disease monitoring. To our knowledge, there are no studies on bat fly viruses or bat fly metagenomics. 


\subsubsection{Leeches (phylum Annelida)}

Leeches belong to the phylum Annelida. They can be found in freshwater, terrestrial and marine environments [69]. They feed on various animals, among them birds and reptiles, and can therefore ingest DNA and viruses from various hosts [69-71]. The medicinal leech (Hirudo medicinalis) is able to take up to $15 \mathrm{~mL}$ of blood from its host [71]. Upon feeding, leeches store concentrated blood for several months. Host DNA ingested from the leech can be detected for more than four months, and RNA and DNA viruses (bovine parvovirus, feline calicivirus, equine arteritis virus and equine herpesvirus type 1) absorbed by terrestrial leeches were shown to remain infectious within the leech for up to six months [71-73]. It is feasible that non-infectious DNA or RNA can be detected from the leech for even longer periods. However, not all species of leeches are blood feeding and their distribution is scarce. $90 \%$ of all leeches feed solely on decomposing bodies and open wounds of amphibians, reptiles, waterfowl, fish and mammals [74]. Most species of hematophagous terrestrial leeches live in tropical rainforests of Asia, Madagascar and Australia, areas with sparse human population [75]. Therefore, sampling of leeches for human virus surveillance is challenging.

\subsubsection{Lice}

Lice are wingless arthropods, which live as permanent ectoparasites of birds, mammals and humans. No zoonotic transmission of viruses from lice has been reported, but VEM has been shown successfully for human body lice (Pediculus humanus corporis) engorged in vitro with artificially infected human blood [76].

\section{Combining VEM with iDNA}

As reported by Grubaugh et al., the detection of a canine distemper virus from a mosquito blood meal by using VEM coincided with the detection of canine host DNA from the same sample [9]. This combines VEM with invertebrate-derived DNA (iDNA), a term designating the genetic material ingested by invertebrates feeding on vertebrates [77]. Several studies have shown that iDNA from a variety of vertebrate species can be identified from field-caught animals, including mosquitoes [78,79], carrion flies [59,60,80], biting midges [81], leeches [71,82] and ticks [83]. For the identification of host DNA from arthropod blood meals, PCR-based or serological techniques are traditionally used [84-88]. Recently, a novel high-throughput sequencing approach for identification of host DNA from blood meals was developed [89]. NGS allows the characterization and quantification of the blood meal without the use of host-specific primers. Analyses of the pre-amplified and sequenced 16S ribosomal RNA genes revealed that $83.7 \%$ of all mosquitoes in the study were feeding on one host species exclusively, with human, dog and pig as the most common hosts. Furthermore, analysis of the human hypervariable region I might determine if mosquitoes fed on more than one person. All these findings support that the principle of iDNA can be used to link viruses identified in mosquitoes and other blood-feeding arthropods with their host.

\section{Mosquito Sampling: Practical Considerations}

There are more than 3500 species of mosquitoes described on every continent except for Antarctica [90]. Mosquito sampling is easy and can be conducted passively with light- or $\mathrm{CO}_{2}$-baited traps [91]. Active sampling can involve collecting mosquitoes with hand nets or aspirators [92]. The traditional gold standard for sampling mosquitoes is the human landing catch (HLC) method. HLC requires a volunteer sitting with lower legs exposed to collect mosquitoes that come to feed on them [93]. Despite ethical and safety considerations, HLC is the simplest and most effective method for mosquito sampling. For surveillance of human viruses, resting mosquitoes should be sampled near or in human housing, including house walls, ceilings and bed nets. However, sampling of mosquitoes depends on the mosquitoes' activity in different regions over the year. Seasonal abundance of most mosquito populations decreases during the dry season and peaks during 
the wet season $[94,95]$. In temperate and cold regions mosquitoes die, hibernate or enter diapause; hence sampling cannot be provided throughout the year [96,97]. For some species, mosquitoes are highly host specific, and therefore sampling can represent the virome and abundance of the preferred host [98]. Sampling strategies for VEM should focus on geographic regions where the risk of emergence or re-emergence of viral diseases is high, and include antropophilic as well as zoophilic mosquitoes. Mosquito species of the genus Anopheles are abundant in all geographic emerging disease "hotspots" specified by Jones et al., including the northeastern United States, central America, western Europe, tropical Africa and Southeast Asia [5,99]. Mosquito species such as Anopheles quadrimaculatus in the eastern part of the United States, Anopheles atoparvus in most parts of western Europe or Anopheles gambiae in Africa can be collected in or close to human habitats. For the surveillance of human viruses with VEM, Anopheles quadrimaculatus mosquitoes can be collected from human dwellings, where the human blood feeding rate can reach 93\% [100]. Adult females of Anopheles atoparvus preferably feed on domestic animals but bite humans readily. They can be collected from animal shelters, households or other kinds of human-created habitats [101]. Anopheles gambiae is highly anthropophilic and prefers to feed in human dwellings [98]. After blood feeding, the mosquito rests on interior walls for several hours with limited mobility and can be easily collected [102]. The Aedes aegypti mosquito has evolved to specialize in biting humans, and is a possible species for sampling human viruses in tropical Africa and Southeast Asia [103,104]. Mosquito species of the genus Culex are distributed in most parts of the world. For example, Culex erythrothorax or Culex quinquefasciatus mosquitoes feed on various mammals and birds and can ingest viruses from many different hosts $[98,105]$.

Depending on field conditions and available resources, sampled mosquitoes can be stored frozen in liquid nitrogen or dry ice $[11,13,14]$, preserved in RNA-stabilizing buffer such as RNA-later ${ }^{\circledR}[106]$ or blood meals can be preserved on Flinders Technology Associates (FTA) filter paper cards [9,33,37]. For whole mosquitoes, viral particles can be concentrated and purified during sequential processing, including homogenization, filtration, centrifugation and DNA digestion [11,107-109]. The average blood meal volume of mosquitoes is $2 \mu \mathrm{L}$ (1 $\mu \mathrm{L}$ of serum) [110-112]. Extracted from FTA cards, this volume is suitable for recovering virus sequences from mosquitoes that fed on artificial blood [9,33,37]. Furthermore, blood meals dried on FTA cards can be maintained at room temperature for weeks prior to NGS without needing cold chains for transport and storage, which is important for sampling under remote field conditions or in underdeveloped countries [113,114]. The denaturation and inactivation of viral particles is provided for and makes the handling of FTA-dried blood spots safe, as shown by the complete inactivation of highly pathogenic Avian influenza virus (AIV) one hour after adsorption onto FTA paper [115]. However, FTA cards cannot be used for viral metagenomics or further analyses of virus samples as cell culture inoculations. Therefore, storing mosquito blood meals on FTA cards is a suitable approach for surveying the viral diversity of a given species, neglecting the value of viral isolates and in vitro culture techniques.

\section{Discussion}

VEM has had its concept proven in several publications. Independent feasibility studies have shown that DNA as well as RNA viruses can be identified from mosquitoes fed on artificial blood or infectious animal models $[9,33,37]$. Depending on the virus species, the $50 \%$ endpoint detection of virus copies $/ \mathrm{mL}$ is within the natural clinical ranges of human infections [40-43]. Viral sequences can be detected from the mosquito blood meal for up to $24 \mathrm{~h}[9,37]$. The mosquito midgut is a highly proteolytic environment facilitating the degradation of the blood contents over approximately the first $24 \mathrm{~h}$ after blood ingestion [116]. However, particles of human immunodeficiency virus (HIV) even remained infectious for up to ten days in the blood meals of arthropods, including ticks and mosquitoes [117]. VEM was performed successfully in the field, and sequences of human and animal viruses were detected, none of which were able to be vectored or to replicate in the mosquito $[9,11]$. Furthermore, the detection of a canine virus from a mosquito blood meal by using VEM was linked to 
the detection of canine host DNA [9]. This combines VEM with iDNA, a term for the genetic material ingested by invertebrates feeding on vertebrates [77].

Although VEM is an innovative and promising approach for sampling and surveying viruses from human and wildlife, one of the main challenges will be to estimate the risk for human health based on the viral sequences found in the blood meal. Since most of these sequences will be "novel", poorly characterized, incomplete and of unknown pathology, the pathogenicity can hardly be verified by conventional methods. Fredericks et al. and Mokili et al. recently have adapted Koch's postulates to molecular and NGS data $[118,119]$. Rather than isolation of the pathogen in cell culture, the metagenomic Koch's postulates focus on the identification of "metagenomic traits" as sequence reads or contigs that distinguish metagenomes obtained from healthy donors from those of diseased subjects. As an example, the Merkel cell polyomavirus was identified as the causative agent of Merkel's cell carcinoma [120].

Considering these main pitfalls of VEM, the identification of uncharacterized viral sequences and the missing link to pathology and pathogenicity of these sequences, we suggest that VEM should focus on two different goals. To accelerate the identification of the whole viral diversity, it is necessary to sample a broad range of vertebrates and invertebrates at different places all over the world. Most viruses identified in the viromes of mosquito blood meals were described as "novel" $(<70 \%$ amino acid identity) $[10,36]$. These findings suggest that the viral diversity in mosquitoes and in virus reservoirs has hardly been explored yet. It is estimated that $60 \%-99 \%$ of the sequences generated in different viral metagenomic studies are not homologous to known viruses, and more than 320,000 viruses still await their discovery [109-111]. Because bioinformatics methods mainly use reference-based approaches for sequence identification, they have so far been unable to classify such highly divergent viruses. Cataloguing the viral diversity of different hosts by VEM can contribute to such reference-based approaches, as it might provide the missing sequence link, which can help classifying viral sequences previously described as "unknown". The comparison of catalogued viromes of different hosts over space and time should also focus on changes in the virome composition. As the metagenomic Koch's postulates cannot be verified by distinguishing metagenomics traits of healthy and diseased hosts from the mosquito blood meals, such changes in the virome could be linked to unusual morbidity or mortality events in human and wildlife.

However, VEM can also be applied to easily survey characterized viruses of known pathogenicity over space and time. Since the linkage of such identified viruses to the host is possible with iDNA approaches, the potential health risk might be identified if certain viruses increase remarkably in a given area or emerge in new areas or novel hosts.

\section{Conclusions}

Climate and ecosystem changes, demographics and human behavior have contributed to the increased emergence and re-emergence of viral pathogens globally $[5,7,121]$. Therefore, monitoring and surveillance of the viral diversity of wildlife and humans in today's rapidly changing ecosystems can be the key to predicting EIDs before they spread. Virus surveillance with VEM can provide a novel surveillance approach for the detection and monitoring of pathogens prior to disease outbreak and future epidemics.

Acknowledgments: We thank Ursula Erikli for copyediting.

Conflicts of Interest: The authors declare no conflict of interest.

\section{References}

1. Raj, V.S.; Osterhaus, A.D.; Fouchier, R.A.; Haagmans, B.L. Mers: Emergence of a novel human coronavirus. Curr. Opin. Virol. 2014, 5, 58-62. [CrossRef] [PubMed]

2. Li, D.X. Severe fever with thrombocytopenia syndrome: A newly discovered emerging infectious disease. Clin. Microbiol. Infect. 2015, 21, 614-620. [CrossRef] [PubMed] 
3. Carroll, M.W.; Matthews, D.A.; Hiscox, J.A.; Elmore, M.J.; Pollakis, G.; Rambaut, A.; Hewson, R.; Garcia-Dorival, I.; Bore, J.A.; Koundouno, R.; et al. Temporal and spatial analysis of the 2014-2015 Ebola virus outbreak in West Africa. Nature 2015, 524, 97-101. [CrossRef] [PubMed]

4. Grard, G.; Fair, J.N.; Lee, D.; Slikas, E.; Steffen, I.; Muyembe, J.J.; Sittler, T.; Veeraraghavan, N.; Ruby, J.G.; Wang, C.; et al. A novel rhabdovirus associated with acute hemorrhagic fever in Central Africa. PLoS Pathog. 2012, 8, e1002924. [CrossRef] [PubMed]

5. Jones, K.E.; Patel, N.G.; Levy, M.A.; Storeygard, A.; Balk, D.; Gittleman, J.L.; Daszak, P. Global trends in emerging infectious diseases. Nature 2008, 451, 990-993. [CrossRef] [PubMed]

6. EcoHealth Alliance. EcoHealth Alliance Pandemic Prevention: PREDICT. Available online: http:/ / www.ecohealthalliance.org/program/predict (accessed on 4 May 2016).

7. Temmam, S.; Davoust, B.; Berenger, J.M.; Raoult, D.; Desnues, C. Viral metagenomics on animals as a tool for the detection of zoonoses prior to human infection? Int. J. Mol. Sci. 2014, 15, 10377-10397. [CrossRef] [PubMed]

8. Molaei, G.; Andreadis, T.G.; Armstrong, P.M.; Anderson, J.F.; Vossbrinck, C.R. Host feeding patterns of Culex mosquitoes and West Nile virus transmission, Northeastern United States. Emerg. Infect. Dis. 2006, 12, 468-474. [CrossRef] [PubMed]

9. Grubaugh, N.D.; Sharma, S.; Krajacich, B.J.; Fakoli, L.S., III; Bolay, F.K.; Diclaro, J.W., II; Johnson, W.E.; Ebel, G.D.; Foy, B.D.; Brackney, D.E. Xenosurveillance: A novel mosquito-based approach for examining the human-pathogen landscape. PLoS Negl. Trop. Dis. 2015, 9, e0003628. [CrossRef] [PubMed]

10. Delwart, E.L. Viral metagenomics. Rev. Med. Virol. 2007, 17, 115-131. [CrossRef] [PubMed]

11. Ng, T.F.; Willner, D.L.; Lim, Y.W.; Schmieder, R.; Chau, B.; Nilsson, C.; Anthony, S.; Ruan, Y.; Rohwer, F.; Breitbart, M. Broad surveys of DNA viral diversity obtained through viral metagenomics of mosquitoes. PLoS ONE 2011, 6, e20579. [CrossRef] [PubMed]

12. Ng, T.F.; Duffy, S.; Polston, J.E.; Bixby, E.; Vallad, G.E.; Breitbart, M. Exploring the diversity of plant DNA viruses and their satellites using vector-enabled metagenomics on whiteflies. PLoS ONE 2011, 6, e19050. [CrossRef] [PubMed]

13. Shi, C.; Liu, Y.; Hu, X.; Xiong, J.; Zhang, B.; Yuan, Z. A metagenomic survey of viral abundance and diversity in mosquitoes from Hubei province. PLoS ONE 2015, 10, e129845. [CrossRef] [PubMed]

14. Chandler, J.A.; Liu, R.M.; Bennett, S.N. RNA shotgun metagenomic sequencing of Northern California (USA) mosquitoes uncovers viruses, bacteria, and fungi. Front. Microbiol. 2015, 6. [CrossRef] [PubMed]

15. Coffey, L.L.; Page, B.L.; Greninger, A.L.; Herring, B.L.; Russell, R.C.; Doggett, S.L.; Haniotis, J.; Wang, C.; Deng, X.; Delwart, E.L. Enhanced arbovirus surveillance with deep sequencing: Identification of novel rhabdoviruses and bunyaviruses in Australian mosquitoes. Virology 2014, 448, 146-158. [CrossRef] [PubMed]

16. Bishop-Lilly, K.A.; Turell, M.J.; Willner, K.M.; Butani, A.; Nolan, N.M.; Lentz, S.M.; Akmal, A.; Mateczun, A.; Brahmbhatt, T.N.; Sozhamannan, S.; et al. Arbovirus detection in insect vectors by rapid, high-throughput pyrosequencing. PLoS Negl. Trop. Dis. 2010, 4, e878. [CrossRef] [PubMed]

17. Ma, M.; Huang, Y.; Gong, Z.; Zhuang, L.; Li, C.; Yang, H.; Tong, Y.; Liu, W.; Cao, W. Discovery of DNA viruses in wild-caught mosquitoes using small RNA high throughput sequencing. PLoS ONE 2011, 6, e24758. [CrossRef] [PubMed]

18. Chandler, J.A.; Thongsripong, P.; Green, A.; Kittayapong, P.; Wilcox, B.A.; Schroth, G.P.; Kapan, D.D.; Bennett, S.N. Metagenomic shotgun sequencing of a bunyavirus in wild-caught Aedes aegypti from Thailand informs the evolutionary and genomic history of the Phleboviruses. Virology 2014, 464-465, 312-319. [CrossRef] [PubMed]

19. Li, C.X.; Shi, M.; Tian, J.H.; Lin, X.D.; Kang, Y.J.; Chen, L.J.; Qin, X.C.; Xu, J.; Holmes, E.C.; Zhang, Y.Z. Unprecedented genomic diversity of RNA viruses in arthropods reveals the ancestry of negative-sense RNA viruses. Elife 2015, 4. [CrossRef] [PubMed]

20. Bolling, B.G.; Weaver, S.C.; Tesh, R.B.; Vasilakis, N. Insect-specific virus discovery: Significance for the arbovirus community. Viruses 2015, 7, 4911-4928. [CrossRef] [PubMed]

21. Manzin, A.; Martina, B.E.; Gould, E.A.; Bagnarelli, P.; Sambri, V. Human arthropod-borne viral infections. BioMed Res. Int. 2013, 2013. [CrossRef] [PubMed]

22. Gould, E.A.; Solomon, T. Pathogenic flaviviruses. Lancet 2008, 371, 500-509. [CrossRef]

23. Zacks, M.A.; Paessler, S. Encephalitic alphaviruses. Vet. Microbiol. 2010, 140, 281-286. [CrossRef] [PubMed] 
24. Liu, J.; Guo, L.; Zhang, L.; Wei, Y.; Huang, L.; Wu, H.; Liu, C. Three new emerging subgroups of torque teno sus viruses (TTSuVs) and co-infection of TTSuVswith porcine circovirus type 2 in China. Virol. J. 2013, 10, 1-10. [CrossRef] [PubMed]

25. Barbazan, P.; Thitithanyanont, A.; Misse, D.; Dubot, A.; Bosc, P.; Luangsri, N.; Gonzalez, J.P.; Kittayapong, P. Detection of $\mathrm{H} 5 \mathrm{~N} 1$ avian influenza virus from mosquitoes collected in an infected poultry farm in Thailand. Vector Borne Zoonotic Dis. 2008, 8, 105-109. [CrossRef] [PubMed]

26. Fields, B.N.; Knipe, D.M.; Howley, P.M. Fields Virology; Wolters Kluwer Health/Lippincott Williams \& Wilkins: Philadelphia, PA, USA, 2013.

27. Burd, E.M. Human papillomavirus and cervical cancer. Clin. Microbiol. Rev. 2003, 16, 1-17. [CrossRef] [PubMed]

28. Kremsdorf, D.; Favre, M.; Jablonska, S.; Obalek, S.; Rueda, L.A.; Lutzner, M.A.; Blanchet-Bardon, C.; van Voorst Vader, P.C.; Orth, G. Molecular cloning and characterization of the genomes of nine newly recognized human papillomavirus types associated with epidermodysplasia verruciformis. J. Virol. 1984, 52, 1013-1018. [PubMed]

29. Antonsson, A.; Forslund, O.; Ekberg, H.; Sterner, G.; Hansson, B.G. The ubiquity and impressive genomic diversity of human skin papillomaviruses suggest a commensalic nature of these viruses. J. Virol. 2000, 74, 11636-11641. [CrossRef] [PubMed]

30. Biagini, P.; Gallian, P.; Cantaloube, J.F.; Attoui, H.; de Micco, P.; de Lamballerie, X. Distribution and genetic analysis of TTV and TTMV major phylogenetic groups in French blood donors. J. Med. Virol. 2006, 78, 298-304. [CrossRef] [PubMed]

31. Biagini, P.; Uch, R.; Belhouchet, M.; Attoui, H.; Cantaloube, J.F.; Brisbarre, N.; de Micco, P. Circular genomes related to anelloviruses identified in human and animal samples by using a combined rolling-circle amplification/sequence-independent single primer amplification approach. J. Gen. Virol. 2007, 88, 2696-2701. [CrossRef] [PubMed]

32. Ng, T.F.; Suedmeyer, W.K.; Wheeler, E.; Gulland, F.; Breitbart, M. Novel anellovirus discovered from a mortality event of captive California sea lions. J. Gen. Virol. 2009, 90, 1256-1261. [CrossRef] [PubMed]

33. Kading, R.C.; Biggerstaff, B.J.; Young, G.; Komar, N. Mosquitoes used to draw blood for arbovirus viremia determinations in small vertebrates. PLoS ONE 2014, 9, e99342. [CrossRef] [PubMed]

34. Yuill, T.M. Mosquitoes for drawing blood from small reptiles. Trans. R. Soc. Trop. Med. Hyg. 1969, 63, 407-408. [CrossRef]

35. Yajima, M.; Kanda, T.; Takada, K. Critical role of epstein-barr virus (EBV)-encoded RNA in efficient EBV-induced B-lymphocyte growth transformation. J. Virol. 2005, 79, 4298-4307. [CrossRef] [PubMed]

36. Moormann, A.M.; Snider, C.J.; Chelimo, K. The company malaria keeps: How co-infection with epstein-barr virus leads to endemic burkitt lymphoma. Curr. Opin. Infect. Dis. 2011, 24, 435-441. [CrossRef] [PubMed]

37. Yang, Y.; Garver, L.S.; Bingham, K.M.; Hang, J.; Jochim, R.C.; Davidson, S.A.; Richardson, J.H.; Jarman, R.G. Feasibility of using the mosquito blood meal for rapid and efficient human and animal virus surveillance and discovery. Am. J. Trop. Med. Hyg. 2015, 93, 1377-1382. [CrossRef] [PubMed]

38. Hubalek, Z.; Rudolf, I. Tick-borne viruses in Europe. Parasitol. Res. 2012, 111, 9-36. [CrossRef] [PubMed]

39. Havlikova, S.; Lickova, M.; Klempa, B. Non-viraemic transmission of tick-borne viruses. Acta Virol. 2013, 57, 123-129. [CrossRef] [PubMed]

40. Bente, D.A.; Forrester, N.L.; Watts, D.M.; McAuley, A.J.; Whitehouse, C.A.; Bray, M. Crimean-congo hemorrhagic fever: History, epidemiology, pathogenesis, clinical syndrome and genetic diversity. Antivir. Res. 2013, 100, 159-189. [CrossRef] [PubMed]

41. Tokarz, R.; Williams, S.H.; Sameroff, S.; Sanchez Leon, M.; Jain, K.; Lipkin, W.I. Virome analysis of amblyomma americanum, dermacentor variabilis, and ixodes scapularis ticks reveals novel highly divergent vertebrate and invertebrate viruses. J. Virol. 2014, 88, 11480-11492. [CrossRef] [PubMed]

42. Xia, H.; Hu, C.; Zhang, D.; Tang, S.; Zhang, Z.; Kou, Z.; Fan, Z.; Bente, D.; Zeng, C.; Li, T. Metagenomic profile of the viral communities in Rhipicephalus spp. Ticks from Yunnan, China. PLoS ONE 2015, 10, e0121609. [CrossRef] [PubMed]

43. Sakamoto, J.M.; Ng, T.F.; Suzuki, Y.; Tsujimoto, H.; Deng, X.; Delwart, E.; Rasgon, J.L. Bunyaviruses are common in male and female Ixodes scapularis ticks in central Pennsylvania. PeerJ 2016, 4, e2324. [CrossRef] [PubMed] 
44. Moutailler, S.; Popovici, I.; Devillers, E.; Vayssier-Taussat, M.; Eloit, M. Diversity of viruses in ixodes ricinus, and characterization of a neurotropic strain of eyach virus. New Microbes New Infect. 2016, 11, 71-81. [CrossRef] [PubMed]

45. Obenchain, F.D.; Galun, R. (Eds.) Physiology of Ticks. Current Themes in Tropical Science; Pergamon Press: Oxford, UK, 1983; Volume 1.

46. Gariepy, T.D.; Lindsay, R.; Ogden, N.; Gregory, T.R. Identifying the last supper: Utility of the DNA barcode library for bloodmeal identification in ticks. Mol. Ecol. Resour. 2012, 12, 646-652. [CrossRef] [PubMed]

47. Wodecka, B.; Rymaszewska, A.; Skotarczak, B. Host and pathogen DNA identification in blood meals of nymphal ixodes ricinus ticks from forest parks and rural forests of Poland. Exp. Appl. Acarol. 2013, 62, 543-555. [CrossRef] [PubMed]

48. Ginsberg, H.S.; Ewing, C.P. Comparison of flagging, walking, trapping, and collecting from hosts as sampling methods for northern deer ticks, Ixodes dammini, and lone-star ticks, Amblyomma Americanum (Acari: Ixodidae). Exp. Appl. Acarol. 1989, 7, 313-322. [CrossRef] [PubMed]

49. Carpenter, S.; Groschup, M.H.; Garros, C.; Felippe-Bauer, M.L.; Purse, B.V. Culicoides biting midges, arboviruses and public health in Europe. Antivir. Res. 2013, 100, 102-113. [CrossRef] [PubMed]

50. Temmam, S.; Monteil-Bouchard, S.; Robert, C.; Baudoin, J.P.; Sambou, M.; Aubadie-Ladrix, M.; Labas, N.; Raoult, D.; Mediannikov, O.; Desnues, C. Characterization of viral communities of biting midges and identification of novel thogotovirus species and rhabdovirus genus. Viruses 2016, 8. [CrossRef] [PubMed]

51. Beer, M.; Conraths, F.J.; van der Poel, W.H. "Schmallenberg virus"-A novel orthobunyavirus emerging in Europe. Epidemiol. Infect. 2013, 141, 1-8. [CrossRef] [PubMed]

52. Fall, M.; Diarra, M.; Fall, A.G.; Balenghien, T.; Seck, M.T.; Bouyer, J.; Garros, C.; Gimonneau, G.; Allene, X.; Mall, I.; et al. Culicoides (Diptera: Ceratopogonidae) midges, the vectors of african horse sickness virus-A host/vector contact study in the Niayes area of Senegal. Parasites Vectors 2015, 8. [CrossRef] [PubMed]

53. Mellor, P.S.; Boorman, J.; Baylis, M. Culicoides biting midges: Their role as arbovirus vectors. Annu. Rev. Entomol. 2000, 45, 307-340. [CrossRef] [PubMed]

54. Temmam, S.; Monteil-Bouchard, S.; Sambou, M.; Aubadie-Ladrix, M.; Azza, S.; Decloquement, P.; Khalil, J.Y.; Baudoin, J.P.; Jardot, P.; Robert, C.; et al. Faustovirus-like asfarvirus in hematophagous biting midges and their vertebrate hosts. Front. Microbiol. 2015, 6. [CrossRef] [PubMed]

55. Sawabe, K.; Hoshino, K.; Isawa, H.; Sasaki, T.; Hayashi, T.; Tsuda, Y.; Kurahashi, H.; Tanabayashi, K.; Hotta, A.; Saito, T.; et al. Detection and isolation of highly pathogenic H5N1 avian influenza A viruses from blow flies collected in the vicinity of an infected poultry farm in Kyoto, Japan, 2004. Am. J. Trop. Med. Hyg. 2006, 75, 327-332. [PubMed]

56. Chakrabarti, S.; King, D.J.; Afonso, C.; Swayne, D.; Cardona, C.J.; Kuney, D.R.; Gerry, A.C. Detection and isolation of exotic newcastle disease virus from field-collected flies. J. Med. Entomol. 2007, 44, 840-844. [CrossRef] [PubMed]

57. Calibeo-Hayes, D.; Denning, S.S.; Stringham, S.M.; Guy, J.S.; Smith, L.G.; Watson, D.W. Mechanical transmission of Turkey coronavirus by domestic houseflies (Musca Domestica Linnaeaus). Avian Dis. 2003, 47, 149-153. [CrossRef]

58. Tan, S.W.; Yap, K.L.; Lee, H.L. Mechanical transport of rotavirus by the legs and wings of musca domestica (Diptera: Muscidae). J. Med. Entomol. 1997, 34, 527-531. [CrossRef] [PubMed]

59. Schubert, G.; Stockhausen, M.; Hoffmann, C.; Merkel, K.; Vigilant, L.; Leendertz, F.H.; Calvignac-Spencer, S. Targeted detection of mammalian species using carrion fly-derived DNA. Mol. Ecol. Resour. 2015, 15, $285-294$. [CrossRef] [PubMed]

60. Calvignac-Spencer, S.; Merkel, K.; Kutzner, N.; Kuhl, H.; Boesch, C.; Kappeler, P.M.; Metzger, S.; Schubert, G.; Leendertz, F.H. Carrion fly-derived DNA as a tool for comprehensive and cost-effective assessment of mammalian biodiversity. Mol. Ecol. 2013, 22, 915-924. [CrossRef] [PubMed]

61. Goddard, J.; deShazo, R. Bed bugs (Cimex lectularius) and clinical consequences of their bites. JAMA 2009, 301, 1358-1366. [CrossRef] [PubMed]

62. Delaunay, P.; Blanc, V.; del Giudice, P.; Levy-Bencheton, A.; Chosidow, O.; Marty, P.; Brouqui, P. Bedbugs and infectious diseases. Clin. Infect. Dis. 2011, 52, 200-210. [CrossRef] [PubMed]

63. Vail Mayans, M.; Hall, A.J.; Inskip, H.M.; Chotard, J.; Lindsay, S.W.; Alonso, P.L.; Coromina, E.; Mendy, M.; Whittle, H. Risk factors for transmission of hepatitis B virus to Gambian children. Lancet 1990, 336, 1107-1109. [CrossRef] 
64. Webb, P.A.; Happ, C.M.; Maupin, G.O.; Johnson, B.J.; Ou, C.Y.; Monath, T.P. Potential for insect transmission of HIV: Experimental exposure of cimex hemipterus and toxorhynchites amboinensis to human immunodeficiency virus. J. Infect. Dis. 1989, 160, 970-977. [CrossRef] [PubMed]

65. Vobis, M.; D'Haese, J.; Mehlhorn, H.; Mencke, N. Evidence of horizontal transmission of feline leukemia virus by the cat flea (Ctenocephalides felis). Parasitol. Res. 2003, 91, 467-470. [CrossRef] [PubMed]

66. Mead-Briggs, A.R.; Vaughan, J.A. The differential transmissibility of myxoma virus strains of differing virulence grades by the rabbit flea spilopsyllus cuniculi (Dale). Epidemiol. Infect. 1975, 75, 237-247. [CrossRef]

67. Dick, C.W.; Patterson, B.D. Bat flies: Obligate ectoparasites of bats. In Micromammals and Macroparasites: From Evolutionary Ecology to Management; Morand, S., Krasnov, B.R., Poulin, R., Eds.; Springer: Tokyo, Japan, 2006; pp. 179-194.

68. Kohl, C.; Kurth, A. European bats as carriers of viruses with zoonotic potential. Viruses 2014, 6, 3110-3128. [CrossRef] [PubMed]

69. Sawyer, R.T. Leech Biology and Behaviour: Feeding Biology, Ecology, and Systematics; Clarendon Press: Oxford, UK, 1986.

70. Rocha, R.; Borda, E.; Andreone, F.; Rosa, G.M. First reports of leech parasitism in malagasy anurans. Comp. Parasitol. 2012, 79, 352-356. [CrossRef]

71. Schnell, I.B.; Thomsen, P.F.; Wilkinson, N.; Rasmussen, M.; Jensen, L.R.; Willerslev, E.; Bertelsen, M.F.; Gilbert, M.T. Screening mammal biodiversity using DNA from leeches. Curr. Biol. 2012, 22, R262-R263. [CrossRef] [PubMed]

72. Al-Khleif, A.; Roth, M.; Menge, C.; Heuser, J.; Baljer, G.; Herbst, W. Tenacity of mammalian viruses in the gut of leeches fed with porcine blood. J. Med. Microbiol. 2011, 60, 787-792. [CrossRef] [PubMed]

73. Shope, R.E. The leech as a potential virus reservoir. J. Exp. Med. 1957, 105, 373-382. [CrossRef] [PubMed]

74. Mann, K.H. Leeches (Hirudinea) Their Structure, Physiology, Ecology and Embryology with an Appendix on the Systematics of Marine Leeches; Mann, K.H., Knight-jones, W., Eds.; Pergamon Press: New York, NY, USA, 1962.

75. Borda, E.; Oceguera-Figueroa, A.; Siddall, M.E. On the classification, evolution and biogeography of terrestrial haemadipsoid leeches (hirudinida: Arhynchobdellida: Hirudiniformes). Mol. Phylogenet. Evol. 2008, 46, 142-154. [CrossRef] [PubMed]

76. Temmam, S.; Monteil-Bouchard, S.; Robert, C.; Pascalis, H.; Michelle, C.; Jardot, P.; Charrel, R.; Raoult, D.; Desnues, C. Host-associated metagenomics: A guide to generating infectious RNA viromes. PLoS ONE 2015, 10, e0139810. [CrossRef] [PubMed]

77. Calvignac-Spencer, S.; Leendertz, F.H.; Gilbert, M.T.; Schubert, G. An invertebrate stomach's view on vertebrate ecology: Certain invertebrates could be used as "vertebrate samplers" and deliver DNA-based information on many aspects of vertebrate ecology. Bioessays 2013, 35, 1004-1013. [CrossRef] [PubMed]

78. Kent, R.J.; Norris, D.E. Identification of mammalian blood meals in mosquitoes by a multiplexed polymerase chain reaction targeting cytochrome B. Am. J. Trop. Med. Hyg. 2005, 73, 336-342. [PubMed]

79. Kent, R.; Juliusson, L.; Weissmann, M.; Evans, S.; Komar, N. Seasonal blood-feeding behavior of Culex tarsalis (Diptera: Culicidae) in weld county, Colorado, 2007. J. Med. Entomol. 2009, 46, 380-390. [CrossRef] [PubMed]

80. Bohmann, K.; Schnell, I.B.; Gilbert, M.T.P. When bugs reveal biodiversity. Mol. Ecol. 2013, $22,909-911$. [CrossRef] [PubMed]

81. Lassen, S.B.; Nielsen, S.A.; Kristensen, M. Identity and diversity of blood meal hosts of biting midges (Diptera: Ceratopogonidae: Culicoides latreille) in Denmark. Parasites Vectors 2012, 5. [CrossRef] [PubMed]

82. Schnell, I.B.; Sollmann, R.; Calvignac-Spencer, S.; Siddall, M.E.; Yu, D.W.; Wilting, A.; Gilbert, M.T. iDNA from terrestrial haematophagous leeches as a wildlife surveying and monitoring tool-Prospects, pitfalls and avenues to be developed. Front. Zool. 2015, 12. [CrossRef] [PubMed]

83. Allan, B.F.; Goessling, L.S.; Storch, G.A.; Thach, R.E. Blood meal analysis to identify reservoir hosts for amblyomma americanum ticks. Emerg. Infect. Dis. 2010, 16, 433-440. [CrossRef] [PubMed]

84. Kent, R.J. Molecular methods for arthropod bloodmeal identification and applications to ecological and vector-borne disease studies. Mol. Ecol. Resour. 2009, 9, 4-18. [CrossRef] [PubMed]

85. Molaei, G.; Andreadis, T.G.; Armstrong, P.M.; Diuk-Wasser, M. Host-feeding patterns of potential mosquito vectors in connecticut, U.S.A.: Molecular analysis of bloodmeals from 23 species of Aedes, Anopheles, Culex, Coquillettidia, Psorophora, and Uranotaenia. J. Med. Entomol. 2008, 45, 1143-1151. [CrossRef] 
86. Pitzer, J.B.; Kaufman, P.E.; Tenbroeck, S.H.; Maruniak, J.E. Host blood meal identification by multiplex polymerase chain reaction for dispersal evidence of stable flies (Diptera:Muscidae) between livestock facilities. J. Med. Entomol. 2011, 48, 53-60. [CrossRef] [PubMed]

87. Thiemann, T.C.; Brault, A.C.; Ernest, H.B.; Reisen, W.K. Development of a high-throughput microsphere-based molecular assay to identify 15 common bloodmeal hosts of Culex mosquitoes. Mol. Ecol. Resour. 2012, 12, 238-246. [CrossRef] [PubMed]

88. Beier, J.C.; Perkins, P.V.; Wirtz, R.A.; Koros, J.; Diggs, D.; Gargan, T.P., II; Koech, D.K. Bloodmeal identification by direct enzyme-linked immunosorbent assay (ELISA), tested on Anopheles (Diptera: Culicidae) in Kenya. J. Med. Entomol. 1988, 25, 9-16. [CrossRef] [PubMed]

89. Logue, K.; Keven, J.B.; Cannon, M.V.; Reimer, L.; Siba, P.; Walker, E.D.; Zimmerman, P.A.; Serre, D. Unbiased characterization of Anopheles mosquito blood meals by targeted high-throughput sequencing. PLoS Negl. Trop. Dis. 2016, 10, e0004512. [CrossRef] [PubMed]

90. Becker, N.; Petric, D.; Zgomba, M.; Boase, C.; Minoo, M.; Dahl, C.; Kaiser, A. Mosquitoes and Their Control; Springer: Berlin/Heidelberg, Germany, 2010.

91. Brown, H.E.; Paladini, M.; Cook, R.A.; Kline, D.; Barnard, D.; Fish, D. Effectiveness of mosquito traps in measuring species abundance and composition. J. Med. Entomol. 2008, 45, 517-521. [CrossRef]

92. Vazquez-Prokopec, G.M.; Galvin, W.A.; Kelly, R.; Kitron, U. A new, cost-effective, battery-powered aspirator for adult mosquito collections. J. Med. Entomol. 2009, 46, 1256-1259. [CrossRef] [PubMed]

93. Silver, J.B.; Service, M.W. Mosquito Ecology Field Sampling Methods; Springer: New York, NY, USA, 2008.

94. Kent, R.J.; Thuma, P.E.; Mharakurwa, S.; Norris, D.E. Seasonality, blood feeding behavior, and transmission of plasmodium falciparum by Anopheles arabiensis after an extended drought in Southern Zambia. Am. J. Trop. Med. Hyg. 2007, 76, 267-274. [PubMed]

95. Tirados, I.; Costantini, C.; Gibson, G.; Torr, S.J. Blood-feeding behaviour of the malarial mosquito Anopheles arabiensis: Implications for vector control. Med. Vet. Entomol. 2006, 20, 425-437. [CrossRef] [PubMed]

96. Nasci, R.S.; Savage, H.M.; White, D.J.; Miller, J.R.; Cropp, B.C.; Godsey, M.S.; Kerst, A.J.; Bennett, P.; Gottfried, K.; Lanciotti, R.S. West nile virus in overwintering Culex mosquitoes, New York City, 2000. Emerg. Infect. Dis. 2001, 7, 742-744. [CrossRef] [PubMed]

97. Sulaiman, S.; Service, M.W. Studies on hibernating populations of the mosquito Culex pipiens L. In Southern and Northern England. J. Nat. Hist. 1983, 17, 849-857. [CrossRef]

98. Takken, W.; Verhulst, N.O. Host preferences of blood-feeding mosquitoes. Annu. Rev. Entomol. 2013, 58, 433-453. [CrossRef] [PubMed]

99. Kiszewski, A.; Mellinger, A.; Spielman, A.; Malaney, P.; Sachs, S.E.; Sachs, J. A global index representing the stability of malaria transmission. Am. J. Trop. Med. Hyg. 2004, 70, 486-498. [PubMed]

100. Jensen, T.; Cockburn, A.F.; Kaiser, P.E.; Barnard, D.R. Human blood-feeding rates among sympatric sibling species of Anopheles quadrimaculatus mosquitoes in Northern Florida. Am. J. Trop. Med. Hyg. 1996, 54, 523-525. [PubMed]

101. Ramsdale, C.; Snow, K. Distribution of the genus Anopheles in Europe. Eur. Mosq. Bull. 2000, 1-26.

102. Scott, T.W.; Githeko, A.K.; Fleisher, A.; Harrington, L.C.; Yan, G. DNA profiling of human blood in anophelines from lowland and highland sites in Western Kenya. Am. J. Trop. Med. Hyg. 2006, 75, 231-237. [PubMed]

103. McBride, C.S.; Baier, F.; Omondi, A.B.; Spitzer, S.A.; Lutomiah, J.; Sang, R.; Ignell, R.; Vosshall, L.B. Evolution of mosquito preference for humans linked to an odorant receptor. Nature 2014, 515, 222-227. [CrossRef] [PubMed]

104. Brown, J.E.; Evans, B.R.; Zheng, W.; Obas, V.; Barrera-Martinez, L.; Egizi, A.; Zhao, H.; Caccone, A.; Powell, J.R. Human impacts have shaped historical and recent evolution in Aedes aegypti, the dengue and yellow fever mosquito. Evolution 2014, 68, 514-525. [CrossRef] [PubMed]

105. Walton, W.E.; Workman, P.D.; Tempelis, C.H. Dispersal, survivorship, and host selection of Culex erythrothorax (Diptera: Culicidae) associated with a constructed wetland in Southern California. J. Med. Entomol. 1999, 36, 30-40. [CrossRef] [PubMed]

106. LaBeaud, A.D.; Sutherland, L.J.; Muiruri, S.; Muchiri, E.M.; Gray, L.R.; Zimmerman, P.A.; Hise, A.G.; King, C.H. Arbovirus prevalence in mosquitoes, Kenya. Emerg. Infect. Dis. 2011, 17, 233-241. [CrossRef] [PubMed] 
107. Breitbart, M.; Rohwer, F. Method for discovering novel DNA viruses in blood using viral particle selection and shotgun sequencing. Biotechniques 2005, 39, 729-736. [CrossRef] [PubMed]

108. Kohl, C.; Brinkmann, A.; Dabrowski, P.W.; Radonic, A.; Nitsche, A.; Kurth, A. Protocol for metagenomic virus detection in clinical specimens. Emerg. Infect. Dis. 2015, 21, 48-57. [CrossRef] [PubMed]

109. Datta, S.; Budhauliya, R.; Das, B.; Chatterjee, S.; Vanlalhmuaka; Veer, V. Next-generation sequencing in clinical virology: Discovery of new viruses. World J. Virol. 2015, 4, 265-276. [CrossRef] [PubMed]

110. Konishi, E. Size of blood meals of Aedes albopictus and Culex tritaeniorhynchus (Diptera: Culicidae) feeding on an unrestrained dog infected with Dirofilaria immitis (Spirurida: Filariidae). J. Med. Entomol. 1989, 26, 535-538. [CrossRef] [PubMed]

111. Ogunrinade, A. The measurement of blood meal size in Aedes aegypti (L.). Afr. J. Med. Med. Sci. 1980, 9, 69-71. [PubMed]

112. Sinden, R.E. Plasmodium differentiation in the mosquito. Parassitologia 1999, 41, 139-148. [PubMed]

113. Kraus, R.H.; van Hooft, P.; Waldenstrom, J.; Latorre-Margalef, N.; Ydenberg, R.C.; Prins, H.H. Avian influenza surveillance with FTA cards: Field methods, biosafety, and transportation issues solved. J. Vis. Exp. 2011. [CrossRef] [PubMed]

114. Smit, P.W.; Elliott, I.; Peeling, R.W.; Mabey, D.; Newton, P.N. An overview of the clinical use of filter paper in the diagnosis of tropical diseases. Am. J. Trop. Med. Hyg. 2014, 90, 195-210. [CrossRef] [PubMed]

115. Abdelwhab, E.M.; Luschow, D.; Harder, T.C.; Hafez, H.M. The use of FTA(r) filter papers for diagnosis of avian influenza virus. J. Virol. Methods 2011, 174, 120-122. [CrossRef] [PubMed]

116. Brackney, D.E.; Isoe, J.; Black, W.C.; Zamora, J.; Foy, B.D.; Miesfeld, R.L.; Olson, K.E. Expression profiling and comparative analyses of seven midgut serine proteases from the yellow fever mosquito, Aedes aegypti. J. Insect Physiol. 2010, 56, 736-744. [CrossRef] [PubMed]

117. Day, T.; Mideo, N.; Alizon, S. Why is HIV not vector-borne? Evol. Appl. 2008, 1, 17-27. [CrossRef] [PubMed]

118. Fredericks, D.N.; Relman, D.A. Sequence-based identification of microbial pathogens: A reconsideration of koch's postulates. Clin. Microbiol. Rev. 1996, 9, 18-33.

119. Mokili, J.L.; Rohwer, F.; Dutilh, B.E. Metagenomics and future perspectives in virus discovery. Curr. Opin. Virol. 2012, 2, 63-77. [CrossRef] [PubMed]

120. Feng, H.; Shuda, M.; Chang, Y.; Moore, P.S. Clonal integration of a polyomavirus in human merkel cell carcinoma. Science 2008, 319, 1096-1100. [CrossRef] [PubMed]

121. Morens, D.M.; Folkers, G.K.; Fauci, A.S. The challenge of emerging and re-emerging infectious diseases. Nature 2004, 430, 242-249. [CrossRef] [PubMed]

(C) 2016 by the authors; licensee MDPI, Basel, Switzerland. This article is an open access article distributed under the terms and conditions of the Creative Commons Attribution (CC-BY) license (http://creativecommons.org/licenses/by/4.0/). 